\title{
Novel portable device to analyze the moisture permeability of car seat
}

\section{REZUMAT - ABSTRACT}

\section{Nou dispozitiv portabil pentru analiza permeabilității la umiditate a scaunului auto}

Performanța de confort a scaunelor auto este un factor important în producerea acestora, fiecare strat al scaunului auto fiind testat separat pe aparatele de testare convenționale, care nu au același nivel de performanțe atunci când toate straturile sunt intercalate. Complexitatea designului scaunelor auto și metoda de testare creează o cerere ridicată de dispozitive portabile, care pot măsura performanța de confort a scaunului auto in mod real. În cadrul acestei cercetări este proiectat un dispozitiv portabil nou care funcționează cu senzor de flux de căldură special, fiind conectat la calculator prin USB, valorile fluxului de temperatură al apei și temperatura suprafeței fiind furnizate de software. Senzorii fluxului de căldură măsoară transferul de căldură printr-o suprafață, exprimată în $\mathrm{kw} / \mathrm{m}^{2}$. Software-ul controlează ajustarea plăcii de încălzire utilizând controlerul PID. Dispozitivul este testat cu scaun auto real și prezintă rezultate repetabile și reproductibile.

Cuvinte-cheie: scaun auto, dispozitiv portabil, flux de căldură

\section{Novel portable device to analyze themoisture permeability of car seat}

The comfort performance of car seat is important factor while producing car seats, each layer of the car seat is tested separately on classical testing machines, which lacks the real car seat performance when all layers are sandwiched. The complication of car seat design and the testing method bring a great demand of portable device which can measure the comfort performance of the real car seat. In this research a novel portable device is designed which work with special heat flux sensor and the device is connected to computer by USB port and values of heat flux temperature of the water and temperature of the surface is provided by the software. Heat flux sensors measure the heat transfer through a surface, and are expressed in $\mathrm{kw} / \mathrm{m}^{2}$. The software controls the heating plate adjustment using PID controller. The device is tested with real car seat and shows repeatable and reproducible results.

Keywords: car seat, comfort, portable device, heat flux

\section{INTRODUCTION}

Today, comfort has become a major quality criterion of cars. Comfort in a car is a complex phenomenon and comprises such different aspects as, for example, noise, driving behavior, or ease of handling. One of the most important factors influencing passenger convenience is thermal comfort. Therefore, car manufacturers are paying a lot of attention to this aspect, as can be seen by an increased application of air conditioning in the car [1].

A particularly important aspect of vehicle comfort is the seats. Seats do not only have to have an attractive design or meet specific design criteria for safety reasons, they must also have optimum comfort properties. But seat comfort is much more than just passenger convenience. Scientific findings show that the performance of a driver over long distances significantly decreases if the car seats do not support posture and heat balance as required. This leads to exhaustion and loss of concentration, which, in extreme cases, could result in serious accidents [2, 3].

In addition to ergonomic considerations of comfort, the climatic or thermophysiological comfort of the seat is of particular importance. This indicates whether the seat is able to support the thermoregulation of the body via heat and moisture transport.

\section{PARAMETERS OF SEATING COMFORT}

From the physiological point of view, seat comfort comprises the following four parameters [4]:

i. The initial heat flow following the first contact with the seat. In other words; the sensation of warmth or cold in the first few minutes or even seconds after entering the car.

ii. The dry heat flow on long journeys, i.e. the amount of body heat transferred by the seat.

iii. The ability known as "breathability" to transfer any sweating away from the body. In so-called "normal sitting situations" there is no perceptible perspiration, but, nevertheless, the human body constantly releases moisture (so-called 'insensible perspiration'), which has to be taken away from the body

iv. In the event of heavy perspiration (a car in the summer heat, stressful traffic situations) the ability to absorb perspiration without the seat feeling damp.

\section{Warmth sensation}

$25 \%$ of human body is in contact with car seat and the car seat acts as an extra layer of the clothing thus the effecting parameter of the clothing comfort is the same for car seat thermal comfort as well. 
The passenger is already sensing his first thermal impression of a car seat while entering the vehicle. This initial perception of warmth after sitting depends on the thermal absorptivity of the car seat. It is effected by is its heat capacity of the car seat material. Heat capacity is amount of heat required to raise its temperature one degree. Heat capacity varies with the mass of the cushion and the type of material. Thermal conductivity is also another parameter of the thermal absorbency and the thermal absorptivity should be as low as possible; otherwise a car seat feels cold in the winter time or hot during summer $[1,5]$.

Although this initial feeling may last only a few minutes, it is nevertheless very important for the user's acceptance, as it is being repeated frequently. If a car is used every day during the winter time and each morning the driver is dissatisfied when entering the car, acceptance can be significantly decreased.

During long journeys it is favorable if the seat offers a high steady state heat flow, to minimize the tendency to sweat, whereas for the initial perception a low heat flux is required [3]. Hence a conflict arises between these two scenarios.

This conflict can be overcome, because the cover, which determines the initial perception, is only of minor influence on the steady state heat flux, which is mainly determined by the thermal insulation of the seat. Owing to its greater thickness and, hence, higher thermal insulation in comparison to the cover, the cushion becomes the dominant part.

On the other hand, the heat flux is also dependent on the ventilation in the seat. Ventilation itself is determined by the design of the seat (side supports, surface grooves), the elasticity and air permeability of the cushion and, if present, a fan to enforce ventilation [6].

For the car seats with heating, the dominant seat components are the cover. Other than thermal properties of the car seat cover, heating power and its position are of great importance [7, 8].

As a common material used in car seats, foams are poor conductors of heat and have a low heat capacity. A thin layer of foam (plus cover) warms up to skin temperature when driver sits on it, but does not draw much heat from the body's tissues. In warm environments, or during physical exercise, the body attempts to lose heat but is prevented from doing so in the buttocks area and back rest due to the insulating foam of the cushion. This region may therefore begin to heat, resulting in uncomfortable dampness.

A car sit with impermeable foam can increase the skin temperature $10^{\circ} \mathrm{C}$ in 2 hours and increase of the temperature of the skin will cause sweating [5].

\section{Moisture sensation}

The moisture sensation of the passenger is very important for perceived overall seat comfort. In order to achieve a dry microclimate, the ability, known as 'breathability', of the seat to transport any perspiration formed away from the body is crucial. Not only under warm summer conditions is good water vapour transport necessary, but even when there is no perceptible perspiration. The human body constantly releases moisture, the so-called 'insensible perspiration'. As the skin is not totally water vapour tight, our body loses on average 30 grams of moisture per hour. Because a car seat covers large areas of the body, the seat has to manage a large part of the perspiration formed, and, hence, a considerable amount of moisture [1].

Moisture accumulation results in discomfort and, in some cases, an increased risk of soft tissue damage. Many factors determine the causes and prevention of moisture accumulation.

Generation of excessive quantities of heat can cause the sweating. Sweat is normally generated to assist in the thermoregulation of the body by the evaporation of moisture to cool the surface of the skin. Normally, sweating is suppressed locally by pressure. However, sweating can occur in an uncontrolled manner, independent of thermoregulation as insensible perspiration.

Poor exchange of air is one of the reasons of moisture accumulation if there is poor exchange of air in the supported area and the supported area is thermally insulated by the cushion, the interface temperature can exceed $38^{\circ} \mathrm{C}$, where upon sweating increases rapidly with increasing temperature. So that use of impermeable covers for car seat can increase the moisture accumulation. If materials in close contact with the skin do not "breathe" the sweat from body is not being evaporated so that natural environmental cooling cannot occur and resulting in more heat build-up and more sweating.

Methods for preventing moisture build-up include the use of cushion and cover materials that encourage air exchange between the cushion and skin. Any impermeable layer of car seat will be the barrier for moisture transport and will make the complete structure impermeable so that uncomfortable. Cushions with good heat dissipation characteristics help to reduce moisture build-up, if they include absorbent materials like wool or cotton, it helps to reduce moisture build-up.

Some cushions naturally pump air that is trapped in their structure when compressed. This effect can contribute to maintaining comfortable moisture levels at the cushion/skin interface, if the cushion is fitted with an air permeable cover [5].

One solution to reduce the degree of discomfort can be ventilation of the car seat. This can be the solution of both sense of high temperature and the high moisture. To be able to use the car with ventilation systems it is important that the car seat should have the sufficient air permeability and should give the good distribution of the air [9-12]. Suction or blowing of air is also another parameter that may affect the flow of air in car seats. 
Insertion of a component blocking the transport of moisture (e.g. polyurethane foam of a thickness greater than $5 \mathrm{~mm}$, leather and artificial leather products, flame and the other adhesive lamination of the layers) inside a car seat disqualifies the whole car seat, irrespective of the quality of the remaining components [9]. This is unwanted situation for both with or without ventilation seats. In this case the water vapour absorbency is the car seat cover layer is the only source to remove the moisture from microclimate in between human body and the car seat.

\section{Liquid and moisture transfer}

Liquid and moisture transfer mechanisms in the fibrous textiles include [13-15]:

- Vapour diffusion in the void space

- Absorption, transmission and desorption of the water vapour by the fibres.

- Adsorption and migration of the water vapour along the fibre surface

- Transmission of water vapour by forced convection.

Water vapour moves through textiles as a result of water vapor concentration differences. Fibres absorb water vapor due to their internal chemical compositions and structures. The flow of liquid moisture through the textiles is caused by fibre-liquid molecular attraction at the surface of fibre materials, which is determined mainly by surface tension and effective capillary pore distribution and pathways. Evaporation and/or condensation take place, depending on the temperature and moisture distributions [15].

Moisture vapour transmission parameters are calculated by following different standard methods [16]:

i. Evaporative dish method or control dish method (BS 7209);

ii. Upright cup method or Gore cup method (ASTM E 96-66);

iii. Inverted cup method and desiccant inverted cup method (ASTM F 2298);

iv. The dynamic moisture permeable cell (ASTM $F$ 2298) and

v. The sweating guarded hot plate, skin model (ISO 11092).

\section{METHODOLOGY}

\section{PID controller}

The device is controlled using the PID controller

- Proportional (P)

- Integral (I)

- Derivative (D)

Here is the classic block diagram of a process under PID Control (figure 1 and figure 2).

The ideal version of PID controller is controlled by this equation.

$$
\mu(t)=K p \cdot e(t)+K i \int_{0}^{t} e(\tau) d \tau+K d \frac{d e(t)}{d t}
$$

Where $\mu$ is the control signal and $e-$ the control error. The control signal is thus a sum of three terms:

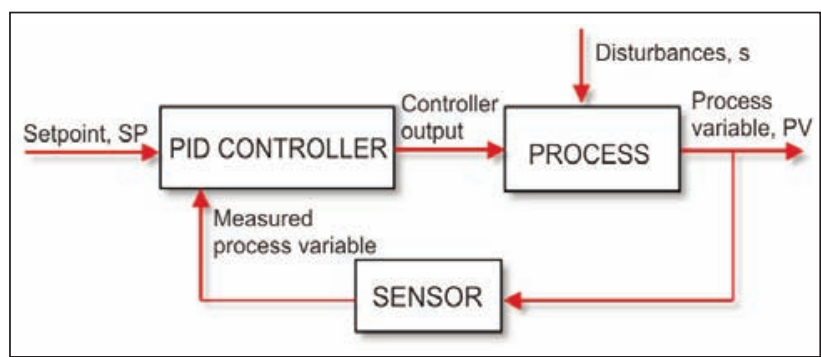

Fig. 1. Block diagram of PID controller

a proportional term that is proportional to the error, an integral term that is proportional to the integral of the error, and a derivative term that is proportional to the derivative of the error. The controller parameters are proportional gain $k p$, integral gain $k i$ and derivative gain $k d$. Proportional-Integral-Derivative (PID) control is the most common control algorithm used in industry and has been universally accepted in industrial control. The popularity of PID controllers can be attributed partly to their robust performance in a wide range of operating conditions and partly to their functional simplicity, which allows engineers to operate them in a simple, straightforward manner.

\section{Proportional response}

The proportional component depends only on the difference between the set point and the process variable. This difference is referred to as the Error term. The proportional gain $\left(K_{c}\right)$ determines the ratio of output response to the error signal. For instance, if the error term has a magnitude of 10 , a proportional gain of 5 would produce a proportional response of 50 . In general, increasing the proportional gain will increase the speed of the control system response. However, if the proportional gain is too large, the process variable will begin to oscillate. If $K_{c}$ is increased further, the oscillations will become larger and the system will become unstable and may even oscillate out of control.

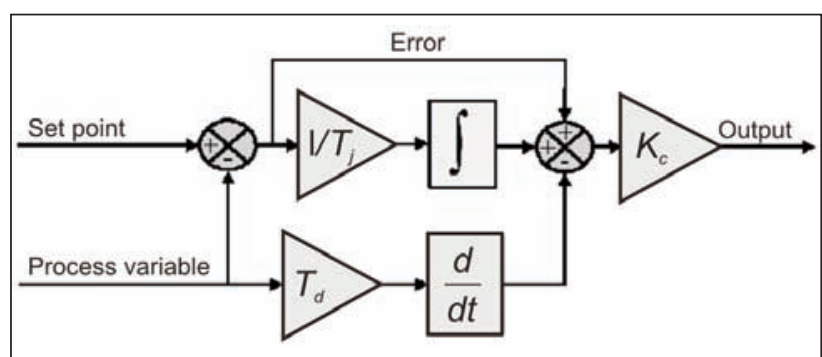

Fig. 2. Block diagram of a basic PID control algorithm

\section{Integral response}

The integral component sums the error term over time. The result is that even a small error term will cause the integral component to increase slowly. The integral response will continually increase over time unless the error is zero, so the effect is to drive the Steady-State error to zero. Steady-State error is the final difference between the process variable and set 
point. A phenomenon called integral windup results when integral action saturates a controller without the controller driving the error signal toward zero.

\section{Derivative response}

The derivative component causes the output to decrease if the process variable is increasing rapidly. The derivative response is proportional to the rate of change of the process variable. Increasing the derivative time $\left(T_{d}\right)$ parameter will cause the control system to react more strongly to changes in the error term and will increase the speed of the overall control system response. Most practical control systems use very small derivative time $\left(T_{d}\right)$, because the Derivative Response is highly sensitive to noise in the process variable signal. If the sensor feedback signal is noisy or if the control loop rate is too slow, the derivative response can make the control system unstable.

\section{Schematic diagram}

The portable device to analyze the comfort performance of car seat is always a dream for the car seat producer. The complication of design and the testing method makes it hard to have a portable device which can measure the comfort performance of the car seat even in uncontrolled condition. Some factors like the moisture permeability under different condition, heat of absorption of material negatively affect the measurement. In this research a first prototype design of device is made and later in future more advancement can be made to the technology.

For this experiment a special heat flux sensor is embedded in a measuring head which is insulated from outside. The heat transfer can be increasing or decreasing and can be in the form of convective, radiative or conductive heat transfer. Heat flux through a thermal resistance layer will create a temperature gradient. Under a temperature gradient, the two thermopile junction layers will be at different temperatures and will therefore register a voltage. The heat flux is proportional to this differential voltage.

The distilled water is added from the tubes above the measuring head and heated to $35^{\circ} \mathrm{C}$. Special microporous membrane (Cellophane) is used on the measuring head to restrict the water drops and allow only the water vapors to pass by. The device is connected to computer by USB port and values of heat flux temperature of the water and temperature of the surface is provided by the software. Heat flux sensors measure the heat transfer through a surface, and are expressed in $\mathrm{kW} / \mathrm{m}^{2}$. The schematic diagram of the device is shown in figures $3-5$.

\section{EXPERIMENTAL PART}

In this research firstly 4 standard car seats are used to test the performance of breathability. For this purpose the car seat's cover is tested for the water vapour permeability under the standard Sweating guarded hotplate by standard ISO11092. The new device is used directly on the car seat and to obtain

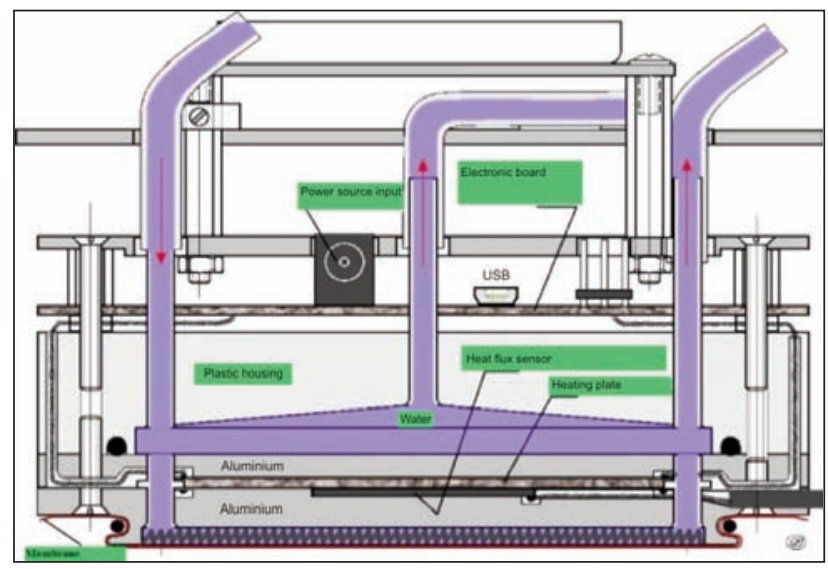

Fig. 3. Schematic diagram of the new device

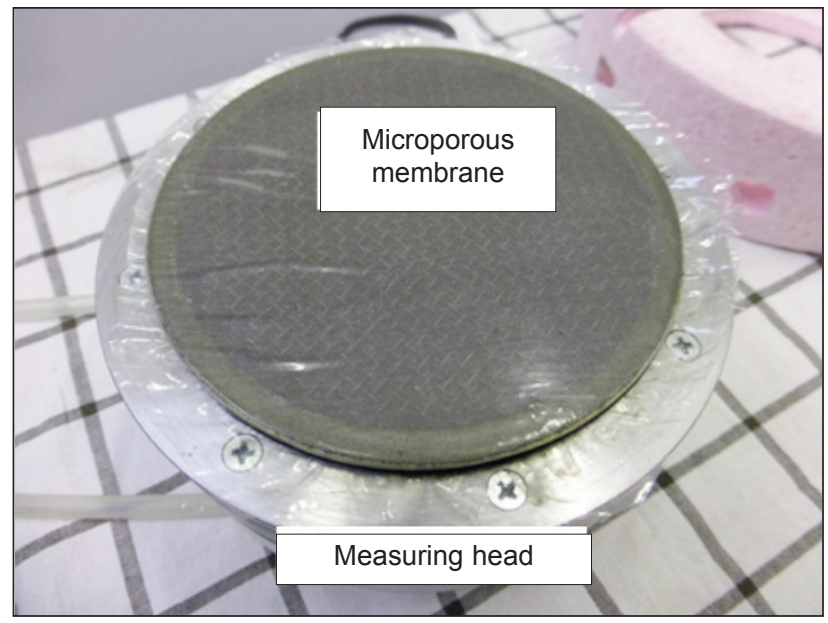

Fig. 4. Measuring head of the new device

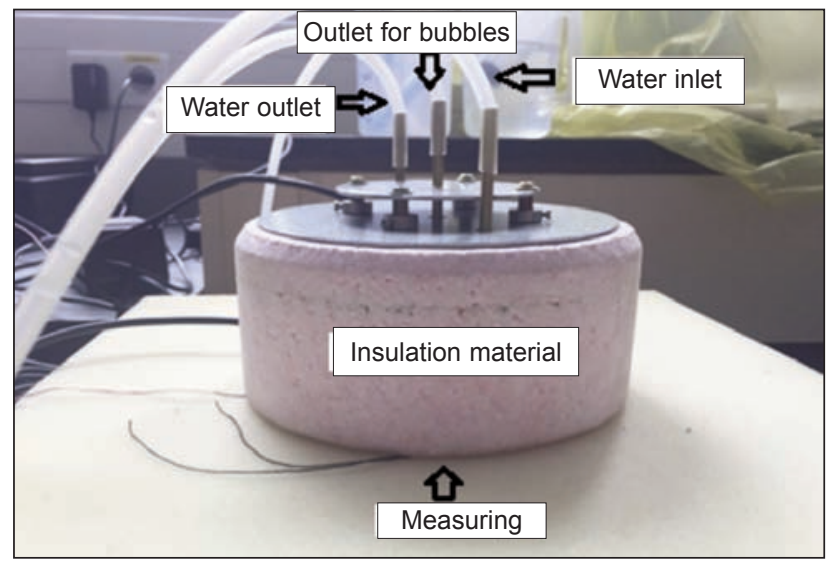

Fig. 5. Part description of the new device

the results, new device is used to test four car seats in actual form to see the performance of device for different car seats and to see the repeatability of the results (figures 6, 7, 8, 9).

The device can be used over a real car seat as shown in figure 10.

After testing on real car seat, the new device is tested with 1 top layers with different backing materials to see the performance of device. The sample properties are shown in table 1. 


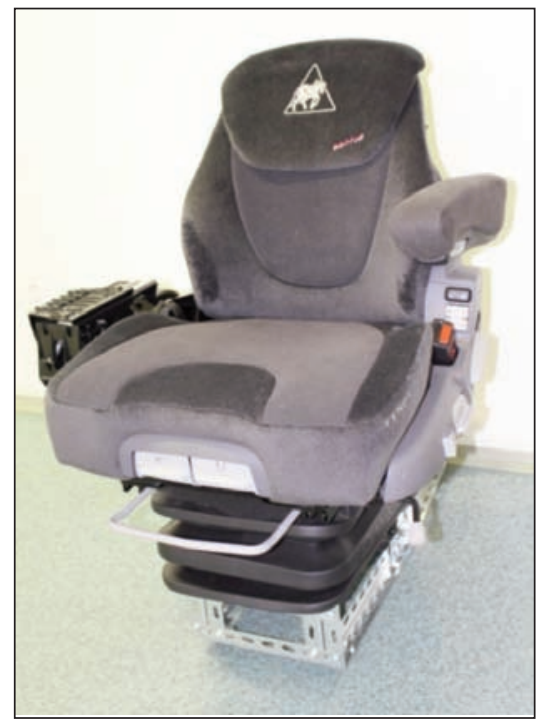

Fig. 6. Tractor seat $A$

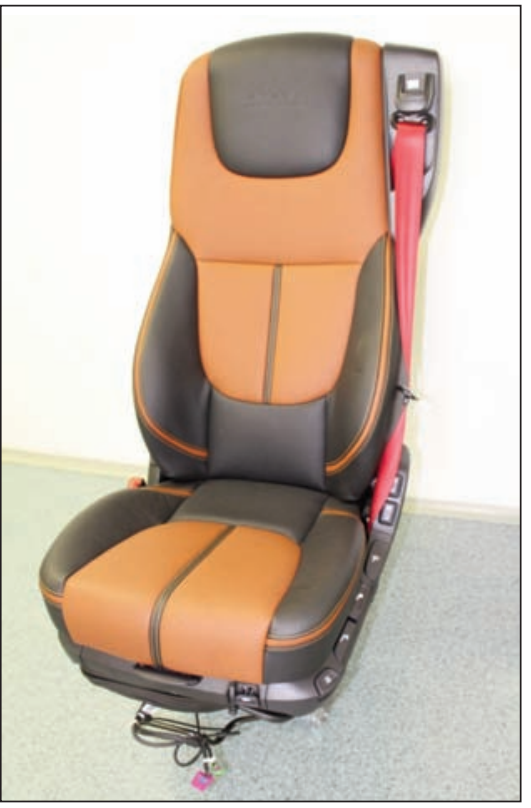

Fig. 9. Truck seat $D$

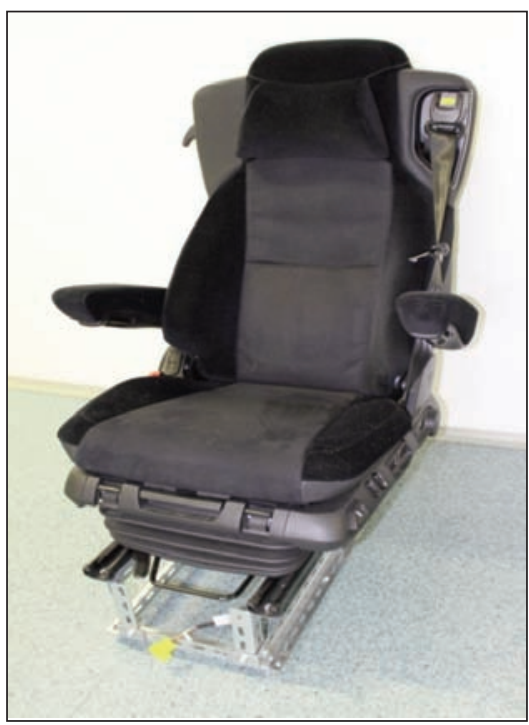

Fig. 7. Truck seat B

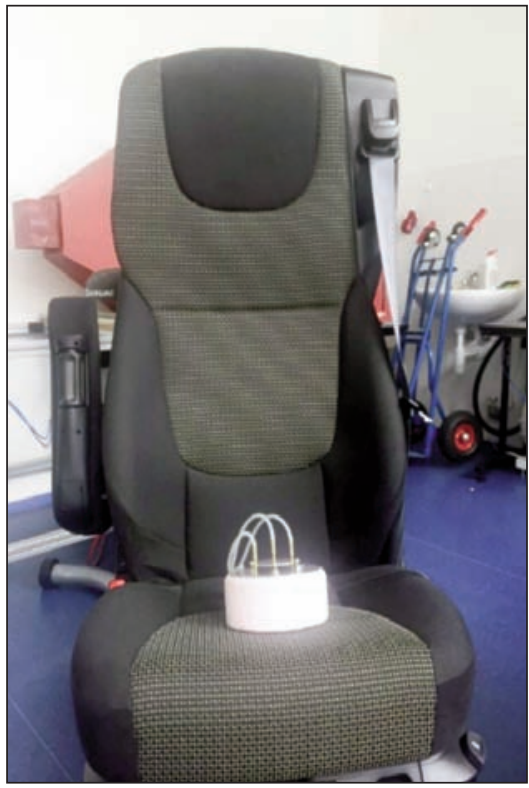

Fig. 10. Portable measuring device on a real car seat

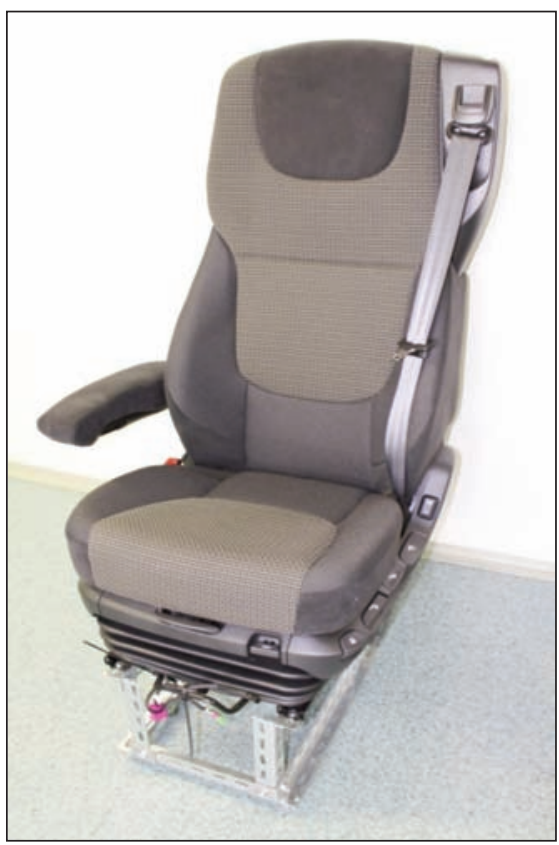

Fig. 8. Truck seat C

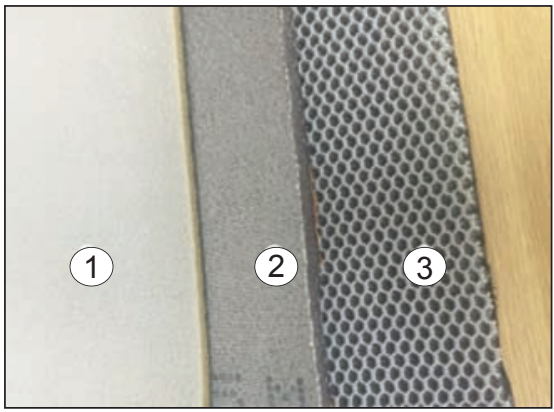

Fig. 11. Top layer with different interlinings

and the real car seat by the new device, results shows similar trend lines.

The table 2 gives us a good idea that the trend of measurement by ATLAS SGHP (Ret) value and the

Table 1

\begin{tabular}{|l|c|}
\hline \multicolumn{1}{|c|}{ Top layer backing material } & $\begin{array}{c}\text { Thickness } \\
{[\mathrm{mm}]}\end{array}$ \\
\hline Plain woven top layer + Classic PU-foam & 5 \\
\hline Plain woven top layer + Retroculated foam & 5 \\
\hline Plain woven top layer + 3D spacer fabric & 5 \\
\hline
\end{tabular}

measurement by the new device are comparable and knowing more information about the temperature and humidity on other side of the sample the Ret value can be also calculated.

The device was also tested for classical and perforated PU cushion as backing. 1 = classic $P U$ foam, 2 = Retroculated foam, $3=3 \mathrm{D}$ spacer fabric.

Table 2

The real pictures of the samples are shown in figure 11.

\section{RESULTS AND DISCUSSION}

The experiment was performed for $30 \mathrm{~min}$ to avoid the initial heat flux change due to the first touch with the sample. Following results are obtained (table 2). The top layer of the four car seats is tested by SGHP

\begin{tabular}{|c|c|c|}
\hline Sample & $\begin{array}{c}\text { Ret }\left[\mathrm{m}^{2} . \mathrm{Pa} / \mathrm{w}\right] \\
\text { (stnd.dev) by standard } \\
\text { SKIN model }\end{array}$ & $\begin{array}{c}\text { New device } \\
{\left[\text { watt } / \mathbf{m}^{2}\right] \text { (stnd.dev) }}\end{array}$ \\
\hline Seat A & $20( \pm 1.67)$ & $149( \pm 5.46)$ \\
\hline Seat B & $39( \pm 2.34)$ & $240( \pm 7.94)$ \\
\hline Seat C & $45( \pm 3.72)$ & $263( \pm 8.21)$ \\
\hline Seat D & $29( \pm 1.55)$ & $164( \pm 3.76)$ \\
\hline
\end{tabular}




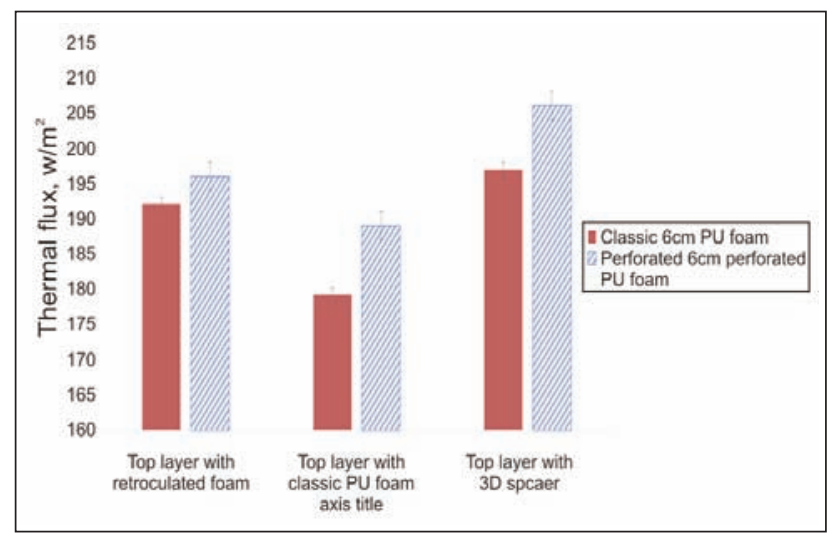

Fig. 12. Effect of perforated and classical PU foam on heat flux

The sandwich material is placed above classical PU cushion foam and perforated PU-foam, following results are achieved as shown in figure 12 .

The results are repeatable and the 3D spacer with the perforated cushion shows highest heat flux.

The device is initial prototype and with further improvement can be a very reliable device to measure the performance of the car seat comfort from a real car seat, without any need to remove the material test separately in testing equipment. The idea is very unique and results are repeatable and the device can be further modified in future.

\section{CONCLUSION}

The newly fabricated device is portable and can be used to obtain the thermal and comfort related properties of the car seat. The device can be used on real car seat and the results are comparable, repeatable and reproducible. It can be seen from the results that the standard testing method of sweating guarded hot plate and this new device shows comparable results. Also the new device takes much less time and is portable and can be used in any part of the samples. The device needs further testing to compare results under different ambient conditions. The device is initial prototype and with further improvement can be a very reliable device to measure the performance of the car seat comfort from a real car seat, without any need to remove the material test separately in testing equipment. The idea is very unique and results are repeatable and the device can be further modified in future.

\section{AKNOWLEDGMENT}

This work was supported by the Ministry of Education, Youth and Sports of the Czech Republic and the European Union - European Structural and Investment funds in the frames of operational program Research, Development and Education - Project Hybrid Materials for Hierarchical Structures (HyHi, Reg. No. CZ.02.1.01/0.0/16_019/0000843).

\section{BIBLIOGRAPHY}

[1] Bartels, V.T. Physiologically optimized car seats, In: Textile advances in Automobile Industry, Woodhead Publishing. 2008, pp. 150-170. ISBN:9781845693312.

[2] Umbach, K.H. Physiologischer SitzkomfortimKfz', In: Kettenwirk-Praxis, 34 (2000a) pp. 34-40.

[3] Umbach, K.H. Parameters for the physiological comfort on car seats In: 38th International Man-Made Fibres Congress, Dornbirn, Austria, 1999.

[4] Sreenivasan, S., Nachane, R.P., Patel, G.S., Chidambareswaran, P.K., Patil, N.B. Parameters related to clothing comfort - diffusive moisture transport evaluation, In: Indian journal of Fibre and Textile Research, vol. 16, 1991, pp. 189-194.

[5] Martin, W. Ferguson-Pell, Seat cushion selection, In: Journal of Rehabilitation Research and Development Clinic Suppl. 1990, vol. 2, pp. 49-73.

[6] Hänel, S.E., Dartman, T., Shishoo, R. Measuring methods for comfort rating of seats and beds, In: International Journal of Industrial Ergonomics, 1997, vol. 20(2), pp. 163-172.

[7] Bartels, V.T. and Umbach, K.H. Physiologically optimised car seats - latest findings and trends, In: 13th Techtextil Symposium, 2005, Frankfurt a.M., Germany.

[8] Hänel, S.E., Dartman, T., Shishoo, R. A new method for measuring mechanical and physiological comfort in car seats, In: 34th International Man-Made Fibres Congress, Dornbirn, Austria, 1995.

[9] Madsen, T.L. Thermal effects of ventilated car seats, In: International Journal of Industrial Ergonomics, 1994, vol. 13, pp. 253-258.

[10] Snycerski, M., Frontczak-Wasiak, I. Influence of furniture covering textiles on moisture transport in a car seat upholstery package, In: AUTEX Research Journal, 2002, vol. 2, no. 3, pp. 126-131.

[11] Aniket, A., Gabhane, A.V. Waghmare, Design of Comfortable Advanced Ventilated Automotive Seat for Driver using CFD simulation, In: International Research Journal of Engineering and Technology, 2016, vol. 03, pp. 1979-1985.

[12] Mazari, Funda Buyuk, Mazari, A., Havelka, A., Wiener, J. Effect of a superabsorbent for the improvement of car seat thermal comfort. In: Fibres\&Textiles in Eastern Europe 2017; 25, 2(122): 81-85. DOI: 10.5604/12303666.1228187. 
[13] Mazari, Funda Buyuk, Chotebor, M., Mazari, A., Naeem, J., Havelka, A. Effect of perforated polyurethane foam on moisture permeability for car seat comfort, In: Fiber and textile in Eastern Europe, vol. (26), 6(120), pp. 14-18, 2016.

[14] Wendl, M.C. Fundamentals of Heat Transfer Theory and Applications, In: Class Notes for ME 371, Department of Mechanical Engineering and School of Medicine Washington University. Available from, https://www.scribd.com/ document/40466365/ht

[15] Holcombe, B.V., Hoschke, B.N. Dry heat transfer characteristics of underwear fabrics, In: Textile Research Journal. 1983, vol. 53, pp. 368-374.

[16] Das, B., Das, A., Kothari, V.K., Fanguiero, R., Araújo. M. Moisture transmission through textiles. Part I: Processes involved in moisture transmission and the factors at play, In: AUTEX Research Journal, 2007, vol. 7, no. 2, pp. $100-110$.

Authors:

FUNDA BUYUK MAZARI

ADNAN MAZARI

ANTONIN HAVELKA

VIERA GLOMBIKOVA

Technical University of Liberec, Faculty of Textile Engineering, Department of Textile Clothing,

Studentska 2, Liberec, 46117, Czech Republic

Corresponding author:

ADNAN MAZARI

e-mail: mazariadnanahmed@gmail.com

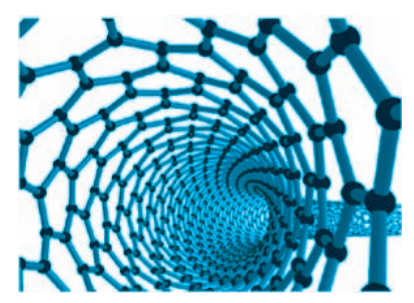

